\title{
Sphagneticola trilobata (Asteraceae): first report of a naturalized plant species for Nepal
}

\author{
Shrestha H.S. ${ }^{1}$, Adhikari B. ${ }^{2 *}$ \& B.B. Shrestha ${ }^{3}$ \\ ${ }^{1}$ Sanothimi Campus, Tribhuvan University, Bhaktapur, Nepal \\ ${ }^{2}$ Royal Botanic Garden Edinburgh, Scotland, UK \\ ${ }^{3}$ Central Department of Botany, Tribhuvan University, Kathmandu, Nepal \\ *E-mail: badhikari@rbge.org.uk
}

\begin{abstract}
Sphagneticola trilobata (L.) Pruski (Asteraceae) is reported here for the first time for the flora of Nepal. The species is recorded from its naturalized populations in the wild from Panchkhal area of Kavrepalanchowk district in central Nepal. A detailed taxonomic description (with colour photographs), notes on habitat and ecology, and its invasion status are provided.
\end{abstract}

Keywords: First report, Flora of Nepal, Invasive species, Naturalized population.

\section{Introduction}

The genus Sphagneticola O.Hoffm. (Asteraceae, Asteroideae: Heliantheae) is a small genus represented by four species, namely $S$. brachycarpa (Baker) Pruski, S. calendulacea (L.) Pruski, S. gracilis (Rich.) Pruski and S. trilobata (L.) Pruski (Funk \& Pruski, 1996; Pruski, 1996; Funk et al., 2009; Fu et al., 2016). Orchard (2013) described S. annua Orchard from Indonesia but the species was not recognized by Pruski (2018) and was treated as a synonym of Baltimora recta L. Of these four species, three $(S$. brachycarpa, $S$. gracilis, and $S$. trilobata) are native to lowland tropics and subtropics of the New World, and S. calendulacea is native to Southeastern Asia and adjacent pacific islands (Funk \& Pruski, 1996).

The genus Sphagneticola is characterized by its stoloniferous growth habit (rooting at nodes), ray corolla limb glandular on the lower surface and three lobed at the apex, and very distinct tuberculate

Received: 06.10.2020; Revised \& Accepted: 25.01.2021

Published Online: 30.06.2021 achenes (Funk \& Pruski, 1996; Pruski, 1996). S. trilobata is a noxious weed particularly in tropical to subtropical Asia and Oceania, and listed in the 100 of the world's worst invasive alien species (Lowe et al., 2000). It exhibits a high ecological tolerance with the adaptive nature suited for dry habitat to wetland. Wet places especially wetlands, riverbanks and ponds are favourable places for the growth of this plant. It can also grow in a wide range of $\mathrm{pH}$ and salinity levels (Song et al., 2009). It forms a dense mat on the ground and significantly reduces the diversity of native plant communities (Qi et al., 2014). Features like herbaceous clonal growth form, semi-aquatic nature, and abiotically dispersed propagules, among others, enable $S$. trilobata to invade both natural areas and agricultural lands (Daehler, 1998).

Specimens of Sphagneticola were collected and photographed during field visits in Kavrepalanchowk district (Fig. 1) in central Nepal during July 2020 to January 2021. The specimens were identified as S. trilobata and reported here for the first time from Nepal.

\section{Materials and Methods}

This paper is based on field studies conducted by the first and third author and studies of herbarium specimens and literature by all authors. The Kavrepalanchowk district was visited multiple times between July 2020 and January 2021 to determine the extent of occurrence of $S$. trilobata, introduction pathways, invasion status (Blackburn et al., 2011), and its impacts. Herbarium specimens of 


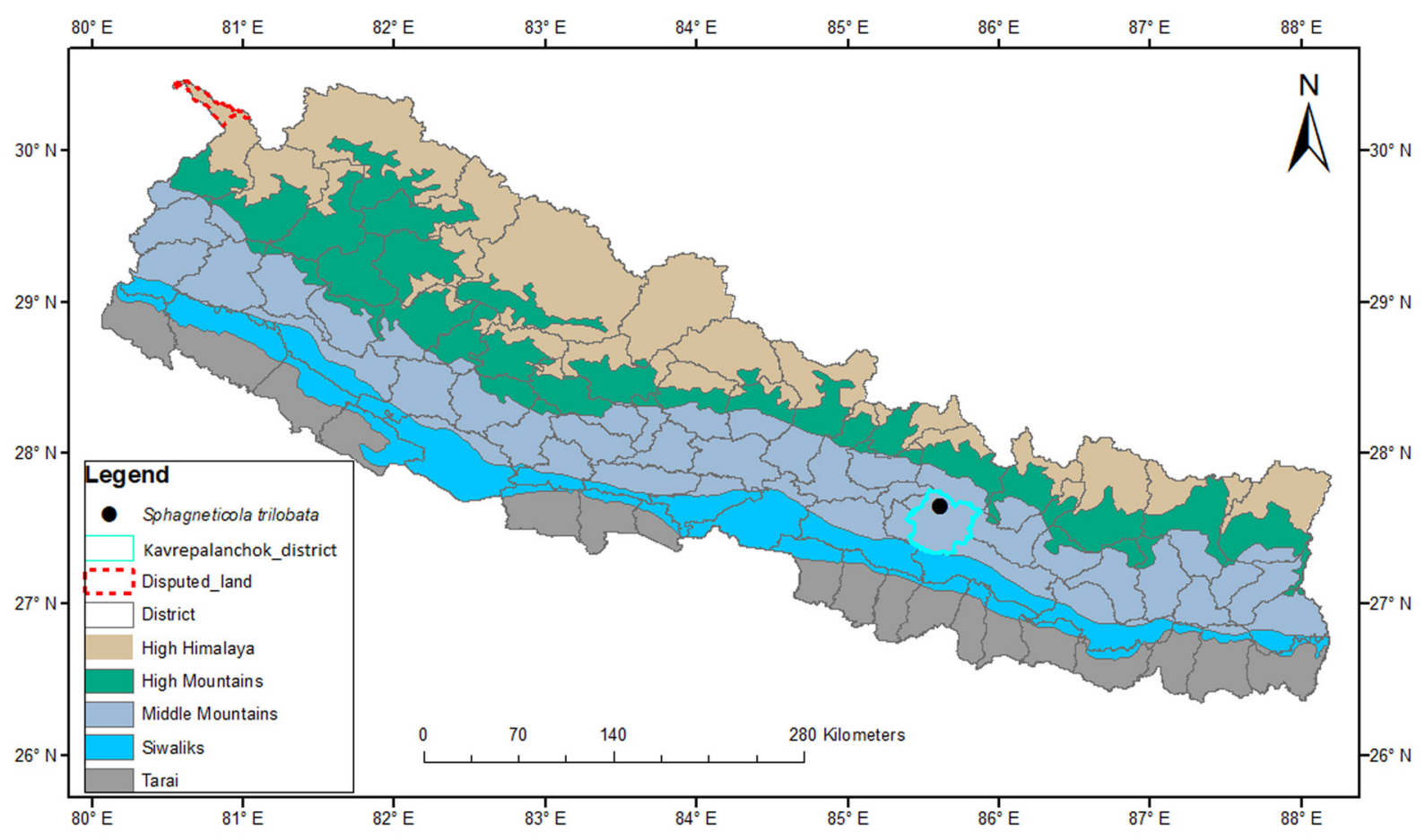

Fig. 1. Map of Nepal showing the location of occurrence of Sphagneticola trilobata (L.) Pruski (Map prepared by Chetmani Chaudhary using ArcGIS ver. 10.5).

Sphagneticola from its native and introduced ranges were checked at E, BM (online images) and $\mathrm{K}$ (online images) herbaria (acronyms follow Thiers, continuously updated). Relevant publications (Funk \& Pruski, 1996; Pruski, 1996; Chen \& Hind, 2011; Orchard, 2013) were also checked. The identification was further confirmed by John F. Pruski, Missouri Botanical Garden (pers. comm., dated 12.09.2020). All the specimens collected during the field visits were deposited at the National Herbarium and Plant Laboratories (KATH) and the Tribhuvan University Central Herbarium (TUCH).

\section{Taxonomic Treatment}

Sphagneticola trilobata (L.) Pruski, Mem. New York Bot. Gard. 78: 114. 1996. Silphium trilobatum L, Syst. Nat., ed. 10. 2: 1233. 1759. Complaya trilobata (L.) Strother, Syst. Bot. Monogr. 33: 14. 1991. Seruneum trilobatum (L.) Kuntze, Revis. Gen. P1. 1: 365. 1891. Stemmodontia trilobata (L.) Small, Fl. S.E. U.S. 1262, 1340. 1903. Thelechitonia trilobata (L.) H.Rob. \& Cuatrec., Phytologia 72(2): 142. 1992. Wedelia trilobata (L.) Hitchc., Rep. (Annual) Missouri Bot. Gard. 4: 99. 1893.
English name: Singapore daisy, Creeping ox-eye, Creeping wedelia.

Fig. 2

Perennial procumbent herbs, up to $1 \mathrm{~m}$ long, terrestrial or semi-aquatic. Stems rooting at nodes, terete, glabrous or sparsely pubescent, green or reddish green. Leaves simple, opposite; petioles absent or up to $3 \mathrm{~mm}$ long; lamina lanceolate to elliptic, 3.4-8.7 × 1.7-4 cm, usually 3-lobed, base cuneate, margins distantly serrate, apex acute, glabrous to puberulent, dark green above, paler below. Capitulum terminal, radiate, many flowered; involucre $c .1 \mathrm{~cm}$ long, involucral bracts in $2(-3)$ series, green; peduncles $5.5-16 \mathrm{~cm}$ long. Ray florets 8-13 per capitulum, pistillate, ligulate; limb oblong to obovate, 7-17 × 2-5 mm, 3-lobed at apex, lower surface glandular, bright yellow. Disc florets many, bisexual, corolla 4-7 mm long, 5-lobed; lobes spreading. Stamens $0.17-0.3 \mathrm{~mm}$ long; anthers 1.2$2.7 \mathrm{~mm}$ long. Pistil 2-3.5 mm long. Achenes pyriform, 2-5 mm long, green when young, brown and tuberculated at maturity; pappus cupuliform, of fused short fimbriate scales.

Flowering \& fruiting: Flowering from March to October and fruiting from May to November. 


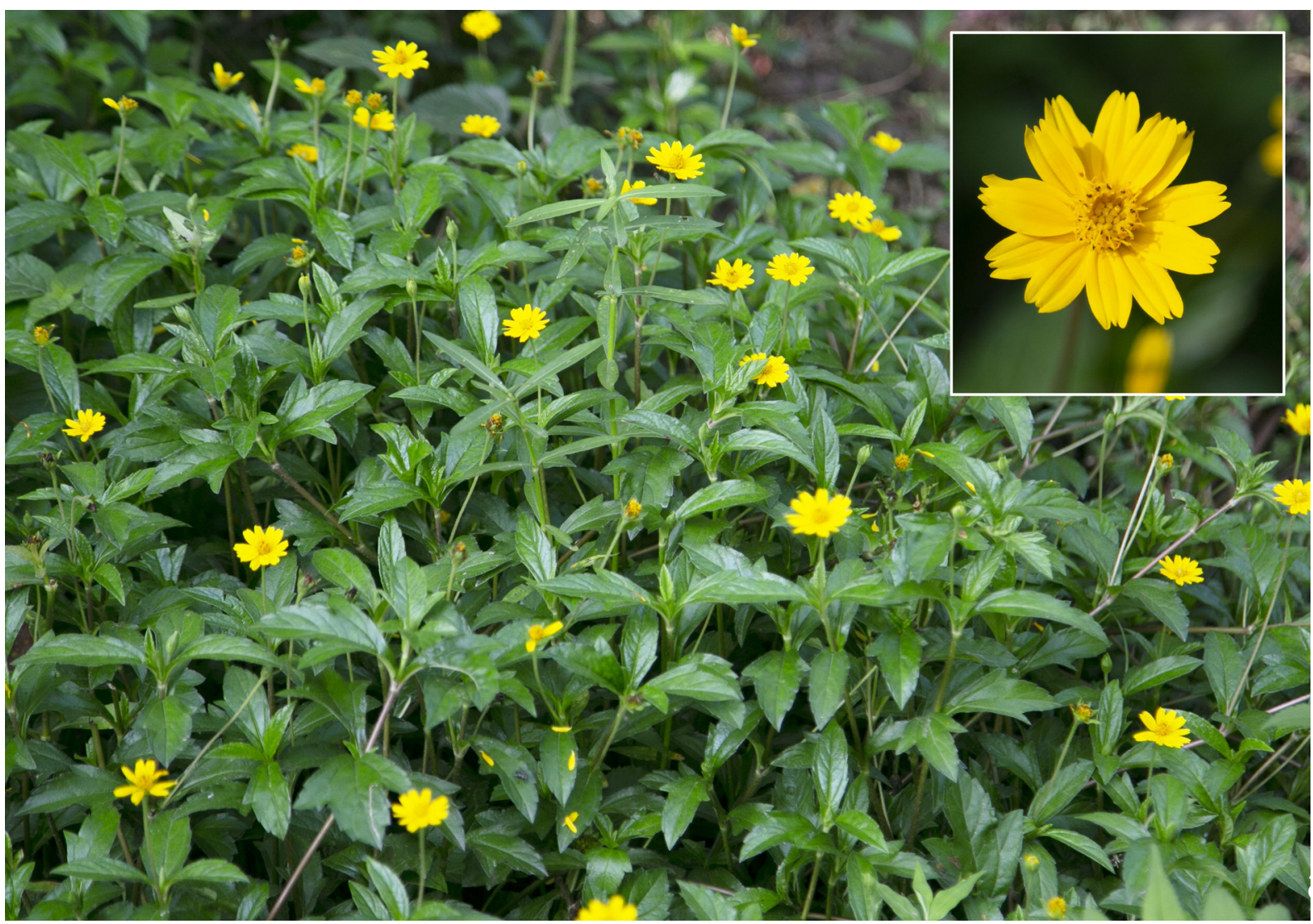

Fig. 2. Sphagneticola trilobata (L.) Pruski. (photos by H.S. Shrestha).

Habitat: Naturalized populations of S. trilobata were found along the roadside, trails, grasslands, streamside, and in agricultural lands at an elevations of 600-900 $\mathrm{m}$ in middle mountain regions of the Kavrepalanchowk district. It was also recorded from forest margins of Alnus nepalensis D.Don (Betulaceae), Pinus roxburghii Sarg. (Pinaceae), and Shorea robusta C.F.Gaertn. (Dipterocarpaceae) dominated forests. On roadsides and in agricultural lands, species such as Heteropogon contortus (L.) P.Beauv., Imperata cylindrica (L.) P.Beauv. (both Poaceae), Galinsoga parviflora Cav. (Asteraceae), Justicia simplex D.Don (Acanthaceae) and Lantana camara L. (Verbenaceae) were associated with S. trilobata.

Distribution: It is a native of tropical Americas with native distribution from Mexico to Brazil and naturalized in tropical to subtropical regions of Asia (e.g. India, China, now also in Nepal), Africa (e.g. Kenya, Benin) and Oceania (e.g. Australia, Micronesia) (CABI, 2020).
Specimens examined: NEPAL, Bagmati province, Kavrepalanchowk district, Panchkhal-03, N $27.64^{\circ}$, E $85.62^{\circ}, 860 \mathrm{~m}, 01.07 .2020$, H.S. Shrestha KPS01 (TUCH, KATH); Panchkhal-02, Kafladi, $\mathrm{N} 27.422^{\circ}$, E $85.612^{\circ}, 874 \mathrm{~m}, 03.07 .2020$, H.S. Shrestha KPS05 (TUCH, KATH); Panchkhal-03, $\mathrm{N} 27.642^{\circ}, \mathrm{E} 85.612^{\circ}, 881 \mathrm{~m}, 03.07 .2020$, H.S. Shrestha KPSO7 (TUCH, KATH); Panchkhal-04, $\mathrm{N} 27.65^{\circ}, \mathrm{E} 85.62^{\circ}, 850 \mathrm{~m}, 09.08 .2020$, H.S. Shrestha KPS09 (TUCH, KATH).

\section{Invasion status in Nepal}

Invasion stage and impacts

Sphagneticola trilobata is presently known to occur only in Panchkhal municipality of Kavrepalanchowk district in central Nepal. The weed is in the stage of 'establishment' (sensu Blackburn et al., 2011) with an extent of occurrence covering c. $15 \mathrm{~km}^{2}$ along a narrow, East-West 


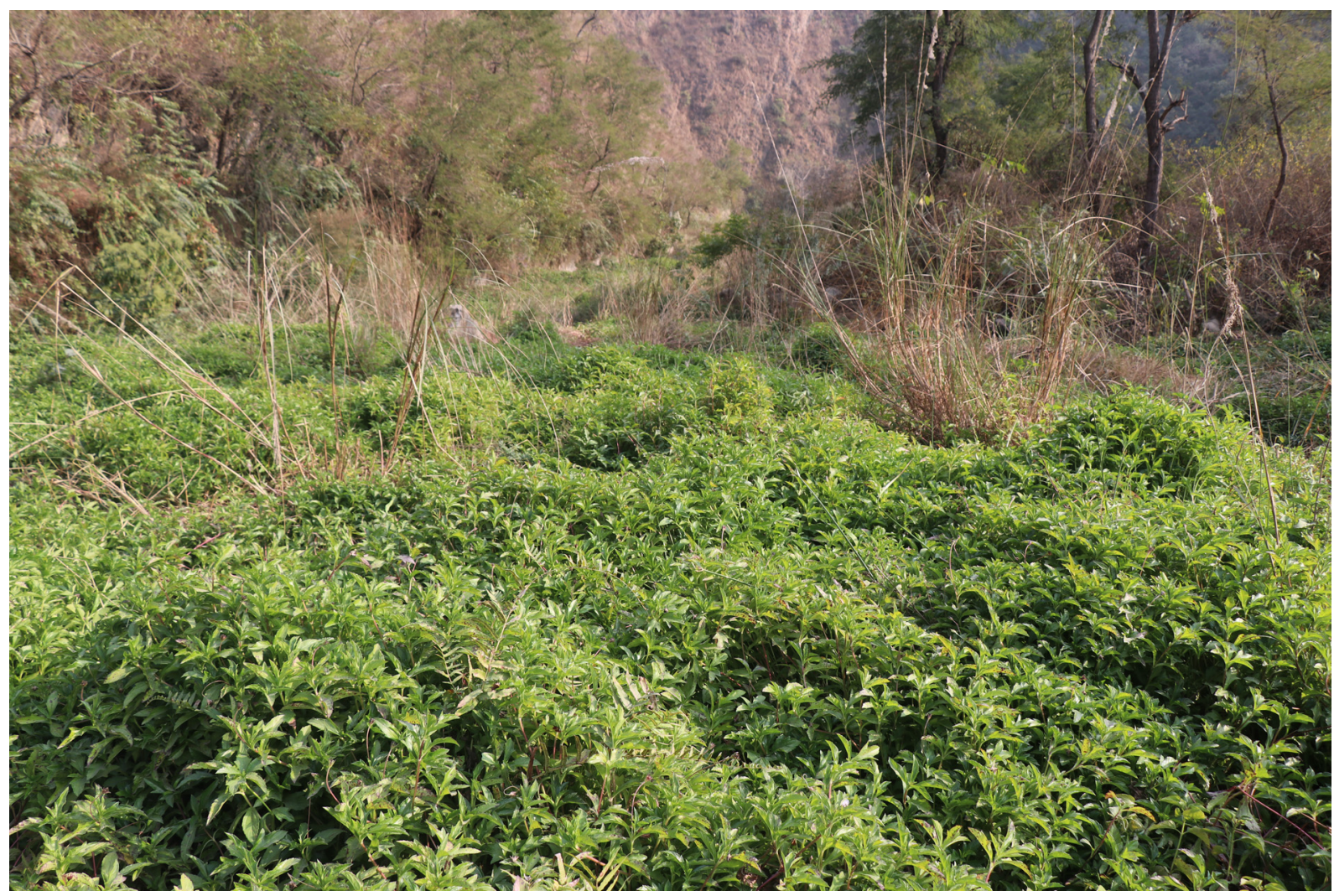

Fig. 3. Dense mat formed by Sphagneticola trilobata (L.) Pruski along streamside (photo by B.B. Shrestha).

running Jhiku Khola (a tributary of the Sunkoshi river), from Panchkhal bazaar to the Sunkoshi river. A socio-economic impact of this weed has not been reported yet by local residents, probably due to its initial stage of invasion. However, ecological impacts were already apparent at the sites of invasion where the weed formed dense mats on the ground, displacing most other plant species (Fig. 3).

Introduction and dispersal pathways

Invasive alien species are usually introduced to a new territory either by nature (i.e. floods, cyclones) or by human interventions (accidentally or intentionally) (Sandilyan, 2015). Major introduction pathways of $S$. trilobata could include the use as an ornamental plant and as contaminants of agriculture and floriculture products (Randall, 2017). Preliminary investigation in Panchkhal Municipality (Kavrepalanchowk district, Nepal) revealed that it was intentionally introduced by a developmental project to prevent soil erosion (Upendra B Baniya, pers. comm. dated 22.10.2020).
Sphagneticola trilobata reproduces both by seeds and stem fragments (Sankaran et al., 2012). Frequent occurrence of this weed along streamside suggests that seeds and stem fragments of this weed can be transported over longer distances during monsoon seasons. Therefore, it is highly likely that this species can turn into a major weed in agricultural lands and natural ecosystems if not managed during its early stage of establishment.

\section{Acknowledgements}

We would like to thank Resham Shrestha and Kabita Humagain for their help during specimen collection and Chetmani Chaudary for preparing the map. Thanks are also due to John F. Pruski (Missouri Botanical Garden), Zoë Goodwin (Royal Botanic Garden Edinburgh), Daolin Du (School of Environment, Jiangsu, China), and KV Sankaran (Kerala, India) for their comments on the species and help with the identification. A field work of BBS to Kavrepalanchowk district was supported 
by Forest Research and Training Center (FRTC), Ministry of Forest and Environment, Kathmandu. The Royal Botanic Garden Edinburgh is supported by the Scottish Government's Rural and Environment Science and Analytical Services Division, and players of the People's Postcode Lottery through the Postcode Earth Trust.

\section{Literature Cited}

BLACKBURN T.M., PYŠEK P., BACHER S., CARLTON J.T., DUNCAN R.P., JAROŠÍK V., WILSON J.R.U. \& D.M. RICHARDSON 2011. A proposed unified framework for biological invasions. Trends in Ecology \& Evolution 26: 333-339. https:// doi.org/10.1016/j.tree.2011.03.023

CABI 2020. Sphagneticola trilobata (Wedelia). In: Invasive species compendium. Wallingford, UK. Available at: www.cabi.org/isc. (Accessed on 20.09.2020).

CHEN Y.S. \& D.J.N. HIND 2011. Heliantheae. In: WU, Z.Y., RAVEN, P.H. \& D.Y. HONG (eds.), Flora of China. Volume 20-21 (Asteraceae). Science Press Beijing \& Missouri Botanical Garden Press, St. Louis. pp. 852878.

DAEHLER C.C. 1998. The taxonomic distribution of invasive angiosperm plants: ecological insights and comparison to agricultural weeds. Biological Conservation 84: 167-180.

FU Z.X., JIAO B.H., NIE B., ZHANG G.J., GAO T.G. \& CHINA PHYLOGENY CONSORTIUM 2016. A comprehensive generic level phylogeny of the sunflower family: implications for the systematics of Chinese Asteraceae. Journal of Systematics and Evolution 54: 416437. https://doi.org/10.1111/jse.12216

FUNK V.A. \& J.F. PRUSKI 1996. Asteraceae. In: ACEVEDO-RODRÍGUEZ P. (ed.), Flora of St. John, U.S. Virgin Islands. Memoirs of the New York Botanical Garden 78: 85-122.

FUNK V.A., SUSANNA A., STUESSY T.F. \& H. ROBINSON 2009. Classification of Compositae. In: FUNK V.A., SUSANNA A., STUESSY T.F. \& R.
BAYER (eds.) Systematics, evolution and biogeography of Compositae. Vienna, IAPT. pp. 171-189.

LOWE S., BROWNE M., BOUDJELAS S. \& M. DE POORTER 2000. 100 of the world's worst invasive alien species: a selection from the Global Invasive Database. Volume 12. International Union for Conservation of Nature (IUCN), Auckland.

ORCHARD A.E. 2013. A new species of Sphagneticola (Asteraceae: Ecliptinae) from Indonesia. Blumea 58: 4952. http://dx.doi.org/10.3767/000651913X671290

PRUSKI J.F. 1996. Compositae of the Guyana HighlandXI. Tuberculocarpus gen. nov. and some other Ecliptinae (Heliantheae). Novon 6: 404-418.

PRUSKI J.F. 2018. Flora Mesoamericana: Asteraceae. Universidad Nacional Autónoma de México, Missouri Botanical Garden, The Natural History Museum (London).

QI S.S., DAI Z.C., ZHAI D.L., CHEN S.C., SI C.C., HUANG P., WANG R.P., ZHONG Q.X. \& D.L. DU 2014. Curvilinear effects of invasive plants on plant diversity: plant community invaded by Sphagneticola trilobata. PLoS ONE 9(11): e113964. https://doi.org/ 10.1371/journal.pone.0113964

RANDALL R.P 2017. A global compendium of weeds. Third edition. R.P. Randall, Perth.

SANDILYAN S. 2015. Highways of India: a heaven to invasive alien plants. Science India 18(12): 33-36.

SANKARAN K.V., SURESH T.A. \& T.V. SAJEEV 2012. Handbook of invasive plants of Kerala. Kerala Forest Research Institute, Kerala.

SONG L., LANG S.L., ZHAN S., HUA L.W. \& P.C. LIAN 2009. Physiological functions of the red leaves of Wedelia trilobata induced by high irradiance in summer. Biodiversity Science 17(2): 188-194. https://doi.org/ 10.3724/SP.J.1003.2009.09007

THIERS B. (continuously updated). Index Herbariorum: A global directory of public herbaria and associated staff. New York Botanical Garden's Virtual Herbarium. Available at: http://sweetgum.nybg.org/science/ih/ (Accessed on 15.09.2020) 